University of Nebraska - Lincoln

DigitalCommons@University of Nebraska - Lincoln

USDA National Wildlife Research Center - Staff Publications
U.S. Department of Agriculture: Animal and Plant Health Inspection Service

4-2011

\title{
Registration Considerations For Chemical Bird Repellents In Fruit Crops
}

John D. Eisemann

USDA/APHIS/WS National Wildlife Research Center, John.D.Eisemann@aphis.usda.gov

Scott J. Werner

USDA-APHIS-Wildlife Services, scott.j.werner@aphis.usda.gov

Jeanette R. O'Hare

USDA APHIS Wildlife Services

Follow this and additional works at: https://digitalcommons.unl.edu/icwdm_usdanwrc

Eisemann, John D.; Werner, Scott J.; and O'Hare, Jeanette R., "Registration Considerations For Chemical Bird Repellents In Fruit Crops" (2011). USDA National Wildlife Research Center - Staff Publications. 1304. https://digitalcommons.unl.edu/icwdm_usdanwrc/1304

This Article is brought to you for free and open access by the U.S. Department of Agriculture: Animal and Plant Health Inspection Service at DigitalCommons@University of Nebraska - Lincoln. It has been accepted for inclusion in USDA National Wildlife Research Center - Staff Publications by an authorized administrator of DigitalCommons@University of Nebraska - Lincoln. 


\title{
REGISTRATION CONSIDERATIONS FOR CHEMICAL BIRD REPELLENTS IN FRUIT CROPS
}

\author{
John D. Eisemann*, Scott J.Werner, and Jeanette R. O'Hare USDA APHIS Wildlife Services, National Wildlife \\ Research Center, 4I0I Laporte Avenue, Fort Collins, CO 8052I, USA *corresponding author, 970-266-6I58, \\ John.D.Eisemann@aphis.usda.gov
}

Keywords: anthraquinone, avian repellent, wildlife damage management, cherries, blueberries, crop protection, pesticide registration

\section{Introduction}

Bird damage has plagued orchardists since the earliest times of cultivation. In a matter of minutes, a flock of birds can literally strip a tree of all harvestable fruit or render hanging fruit unmarketable. While this level of damage is rare, significant economic impact can occur to those orchards where birds select to forage. Crop protection techniques available to orchardists are primarily limited to hazing (scarecrows, propane cannons, flagging) and physical exclusion (netting). Given the propensity of birds to habituate to hazing techniques, hazing methods offer limited protection for crops. Although exclusion devices may offer the best protection from birds, they are expensive to purchase, install, and maintain. As a consequence, orchardists have sought a chemical means of protecting their crops from bird damage. Repellents are, by design, not toxic to the target organism. They may, however, still have undesirable impacts on humans and the environment. Consequently, repellents are subject to the same general registration requirements as traditional agricultural chemicals. As with any chemical application to a food or feed crop, a major hurdle for expanding the use to fruit crops is the establishment of a residue tolerance for applications made during the ripening period.

Between 1972 and 1991, fruit (cherry and blueberry) producers in 10 states were allowed to use methiocarb (as Mesurol) to combat avian damage. In 1987, the United States Environmental Protection Agency (US EPA) published the Registration Standard (US EPA 1987), summarizing the data available to support continued use of methiocarb as an avian repellent in corn fields and fruit orchards, and for slugs and snails in ornamental plantings, lawns, turf and ginseng. The US EPA's review concluded that additional product chemistry, residue chemistry, ecological effects, environmental fate, toxicology and occupational/residential exposure data were needed to continue these uses. Because of the cost associated with generating these data, registrants voluntarily cancelled all uses of methiocarb as a avian repellent and EPA subsequently waived the residue chemistry data requirements for the remaining uses (US EPA 1992). Thus, the primary hurdle facing product registration of an avian repellent for agricultural crops is the establishment of a residue tolerance when applications must be made late in the growing season to protect ripening crops. The time between application and harvest is most often insufficient for desired residue decline before reaching the consumer.

Since 1992, new chemical repellents have been actively sought to protect agricultural crops, but only one (a.i., methyl anthranilate) has been fully registered with the US EPA. Methyl anthranilate is a GRAS-listed (Generally Recognized As Safe) food additive which is commonly used as grape flavoring. It has been demonstrated to be repellent to birds when consumed (Clark et al. 1991) and currently has 8 active product registrations with the US EPA. In 2002, the US EPA exempted methyl anthranilate from the requirement of a residue tolerance (Federal Register: August 7, 2002 (Volume 67, Number 152)). It is registered for bird control on structures, airports, ornamental plantings, turf, fruit crops (berries, grapes, pomes, stonefruit), and grain crops (corn, barley, rice, sorghum, millet, wheat, oats, sunflower), and can be applied in baits, broadcast application or as a fog. Although methyl anthranilate is currently registered as an avian repellent for use in a variety of food crops, independent research has shown that bird damage did not differ between methyl anthranilate-treated versus untreated blueberries (Cummings et al. 1995, Avery et al. 1996). Additionally, it was not effective for repelling blackbirds from ripening rice and sunflower fields (Werner et al. 2005).

This paper presents the data requirements and cost considerations for US EPA product registration of a chemical repellent for protecting fruit crops (e.g., cherries, blueberries) from bird damage. Four approaches to product registration for a food use are presented: 1) development of a new active ingredient; 2) registering an existing avian repellent for use in fruit; 3) registering an existing pesticide formulation as an avian repellent for use in fruit crops; and 4) registering a new formulation of an existing pesticide product as a avian repellant on fruit crops.

\section{General Requirements for Pesticide Registration}

In 2003, the US EPA promulgated the Pesticide Registration Improvement Act (PRIA) (http://www.epa.gov/pesticides/ fees/). This Act established a fee for service structure for pesticide registration actions and corresponding decision review periods for these actions. This act provides a more predictable evaluation process and shorter review periods for reduced-risk pesticide applications. Pesticide registrants are now required to pay PRIA fees upon submission of registration applications or modifications to existing applications. The fees and review time frames presented in this manuscript were published 


\section{CHEMICAL BIRD REPELLENTS}

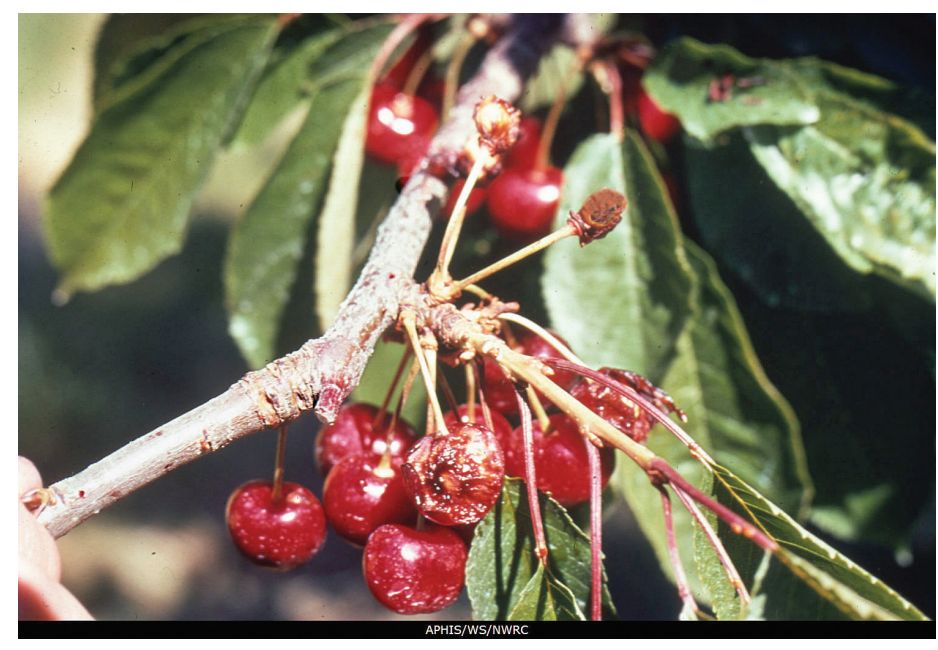

Figure I. Cherries damaged by birds in Northern Michigan, United States. (Photo courtesy of Dr. Richard Dolbeer)

by EPA in August 2010 (Federal Register: August 11, 2010 Volume 75, Number 154).

In 2007, the US EPA set forth amendments to 40 CFR Part 158 'Data Requirements for Pesticides' (US EPA 2007) and thereby expanded the scope of data required to support a product registration. Changes were made to all previous categories of data, and guidelines were developed for addressing new emphasis areas. For a food use of a new active ingredient, the US EPA requires data submission in 9 emphasis areas which can include submission of 146 individual studies or written data submissions; however not all 146 data submissions are required for every pesticide use (Table 1 ). The US EPA also lists an additional 84 studies that may be conditionally required depending upon the toxicity of the active ingredient and the proposed use pattern (e.g., ripening fruit; Table 1). The US EPA provides guidance in 40 CFR Part 158 and individual study guidelines (http://www.epa.gov/pesticides/science/guidelines.htm) on which studies are appropriate given the chemical characteristics of the active ingredient and the use patterns of the proposed product.

\section{Development of a New Active Ingredient}

Our first scenario is the registration of a new active ingredient for use as an avian repellent on ripening fruit. Under this scenario, 151 individual studies are required for an approximate cost of $\$ 7.2$ million (Table 1 ).

The PRIA fee for this scenario in 2011 is $\$ 629,308$. This fee is based on the submission of an application for an Experimental Use Permit (EUP) followed by submission of a registration application. The PRIA review timeframe is 18 months for issuance of the EUP and another 14 months for the registration application.

The approximate total cost for a new active ingredient, including the development of the required data submissions and PRIA fees, is $\$ 7.8$ million. This cost does not include the cost of conducting the studies for assessing post-application exposure, applicator exposure, or spray drift. These data can be generated independently, however over the last 15 years, industry task forces have worked with EPA to conduct generic studies to meet these requirements. Purchasing rights to these data from the respective task forces is a more cost effective approach for meeting these requirements. Access fees are product specific and negotiable, therefore not included in this analysis.

\section{Registering an Existing Avian Repellent for use in Fruit}

Given the high cost associated with registering a new active ingredient, a more economical approach is to either register currently registered avian repellents for additional crops or to investigate pesticides currently registered for use in food crops for their potential as avian repellents.

There is significant monetary and time saving to seeking additional uses of currently registered products. Even if a currently registered product requires reformulation, registration costs are significantly less than those for a new active ingredient. Anthraquinone is currently registered as an avian repellent, but has not been granted a food use registration, except under emergency and state classification. There are a variety of products, discussed below, that currently have food use designations which may be effective bird repellents, but have undergone little to no testing as an avian repellent. These products may or may not require reformulation for avian repellent uses.

Recent laboratory testing of an anthraquinone-based repellent revealed its repellent efficacy as an agricultural crop seed treatment for Canada geese, red-winged blackbirds, and ring-necked pheasants (Werner et al. 2009). Although anthraquinone is a naturally-occurring substance, no anthraquinone-based repellents are currently nationally registered for agricultural applications in the United States. Flight Control Plus (a.i., 9,10-anthraquinone; Arkion Life Sciences) is currently registered for repelling roosting on structures and deterring goose grazing on turf.

Work conducted by the International Crane Foundation (ICF) demonstrated anthraquinone applications as a seed treatment significantly reduced damage caused by sandhill cranes to corn in Wisconsin (ICF unpublished data). In 2007, the US EPA granted an Emergency Use Exemption (FIFRA Section 18 seed treatment labels) to use anthraquinone in Wisconsin to protect newly planted corn from damage caused by sandhill cranes. This seed treatment proved very effective and, as of the 2010 growing season, approval (i.e., Section 18 seed treatment label) to use anthraquinone seed treatments was extended to protect field and sweet corn from crane and blackbird damage in 9 states (www.arkionls.com). Additionally, Section 18 labels have been granted to protect newlyplanted sunflowers from pheasant damage in South Dakota and newly-planted rice from damage caused by blackbirds in Louisiana.

Data required to develop additional uses of current formulations of anthraquinone include residue chemistry data to establish a tolerance, and laboratory and field efficacy data. Since this product has demonstrated avian effectiveness, the data required to support efficacy may be limited in scope. However, securing a food use registration will still require establishing a tolerance and will cost approximately $\$ 743,000$ (Table 1). As mentioned above, this estimate does not include 
Table I. US EPA data requirements and cost estimates (USD) for registering a broadcast applied avian repellent for use on ripening fruit (number of required studies and approximate cost).

\begin{tabular}{|c|c|c|c|c|c|c|}
\hline \multirow[t]{2}{*}{ Data Category } & \multicolumn{3}{|c|}{$\begin{array}{l}\text { EPA Data Requirements for } \\
\text { an Outdoor Food Use }\end{array}$} & \multicolumn{3}{|c|}{ Hypothetical Product } \\
\hline & $\begin{array}{l}\text { Required } \\
\text { Studies }\end{array}$ & $\begin{array}{l}\text { Conditionally } \\
\text { Required } \\
\text { Studies }\end{array}$ & $\begin{array}{l}\text { New Active } \\
\text { Ingredient }\end{array}$ & $\begin{array}{c}\text { Existing Avian } \\
\text { Repellent } \\
\text { (Seeking First } \\
\text { Tolerance) }\end{array}$ & $\begin{array}{l}\text { Existing Food } \\
\text { Use Pesticide } \\
\text { (Seeking an } \\
\text { Additional } \\
\text { Tolerance) }\end{array}$ & $\begin{array}{c}\text { Existing Food } \\
\text { Use Pesticide } \\
\text { Requiring } \\
\text { Reformulation } \\
\text { and an Additional } \\
\text { Tolerance }\end{array}$ \\
\hline Product Chemistry & 27 & 12 & $\begin{array}{c}30 \\
(\$ 134,000)\end{array}$ & 0 & 0 & $\begin{array}{c}20 \\
(\$ 109,000)\end{array}$ \\
\hline Environmental Fate & 9 & 6 & $\begin{array}{c}9 \\
(\$ 700,000)\end{array}$ & 0 & 0 & 0 \\
\hline $\begin{array}{l}\text { Terrestrial and Aquatic } \\
\text { Nontarget Organism }\end{array}$ & 15 & 13 & $\begin{array}{c}15 \\
(\$ 457,000)\end{array}$ & 0 & 0 & 0 \\
\hline $\begin{array}{l}\text { Nontarget Plant } \\
\text { Protection }\end{array}$ & 34 & 36 & $\begin{array}{c}34 \\
(\$ 73,000)\end{array}$ & 0 & 0 & 0 \\
\hline Residue Chemistry & 10 & 6 & $\begin{array}{c}11 \\
(\$ 393,000)\end{array}$ & $\begin{array}{c}10 \\
(\$ 393,000)\end{array}$ & $\begin{array}{c}10 \\
(\$ 323,000)\end{array}$ & $\begin{array}{c}10 \\
(\$ 323,000)\end{array}$ \\
\hline Toxicology & 34 & 7 & $\begin{array}{c}34 \\
(\$ 5,508,000)\end{array}$ & 0 & 0 & 0 \\
\hline $\begin{array}{l}\text { Post-Application } \\
\text { Exposure }^{\prime}\end{array}$ & 9 & 1 & $\begin{array}{c}8 \\
(\$ ?)\end{array}$ & $\begin{array}{c}8 \\
(\$ ?)\end{array}$ & $\begin{array}{c}8 \\
(\$ ?)\end{array}$ & $\begin{array}{c}8 \\
(\$ ?)\end{array}$ \\
\hline Applicator Exposure' & 6 & 1 & $\begin{array}{c}6 \\
(\$ ?)\end{array}$ & $\begin{array}{c}6 \\
(\$ ?)\end{array}$ & $\begin{array}{c}6 \\
(\$ ?)\end{array}$ & $\begin{array}{c}6 \\
(\$ ?)\end{array}$ \\
\hline Spray Drift' & 0 & 2 & $\begin{array}{c}2 \\
(\$ ?)\end{array}$ & $\begin{array}{c}2 \\
(\$ ?)\end{array}$ & $\begin{array}{c}2 \\
(\$ ?)\end{array}$ & $\begin{array}{c}2 \\
(\$ ?)\end{array}$ \\
\hline Product Performance & 2 & 0 & $\begin{array}{c}2 \\
(\$ 350,000)\end{array}$ & $\begin{array}{c}2 \\
(\$ 350,000)\end{array}$ & $\begin{array}{c}2 \\
(\$ 350,000)\end{array}$ & $\begin{array}{c}2 \\
(\$ 350,000)\end{array}$ \\
\hline Data Subtotal & 146 & 84 & $\begin{array}{c}15 \mid \\
(\$ 7,158,000)\end{array}$ & $\begin{array}{c}28 \\
(\$ 743,000)\end{array}$ & $\begin{array}{c}28 \\
(\$ 673,000)\end{array}$ & $\begin{array}{c}48 \\
(\$ 782,000)\end{array}$ \\
\hline PRIA Fee & - & - & $\$ 629,308$ & $\$ 239,684$ & $\$ 59,976$ & $\$ 59,976$ \\
\hline Total & - & - & $\$ 7,787,308$ & $\$ 982,684$ & $\$ 732,976$ & $\$ 841,976$ \\
\hline
\end{tabular}

the cost of post-application exposure, applicator exposure, or spray drift data. PRIA fees associated with an additional food use are $\$ 239,684$ with a review time of 21 months. Total cost of this registration path is therefore approximately $\$ 983,000$.

\section{Registering an Existing Pesticide Formulation as an Avian Repellent for use in Fruit}

Other currently registered chemicals show promise as avian repellents, but are not currently registered for that purpose. Recent avian repellency research focused on crop production has been conducted on chlorpyrifos and gamma-cyhalothrin in rice and sunflower (Werner et al. 2010), azadirachtin (neem extract), and flutolanil, in rice (Werner et al. 2008a), azoxystrobin, difenoconazole, fludioxonil, lambda-cyhalothrin, and propiconazole in rice (Werner et al 2008b), and esfenvalerate, lambda-cyhalothrin, cyfluthrin, tralomethrin, zeta-cypermethrin, endosulfan, boscalid, and chlorpyrifos in sunflower
(Linz et al. 2006). Of the 15 active ingredients tested only flutolanil and propiconazole are promising prospects for further development as an avian repellent in soft fruits.

Werner et al. (2008b) found that the broad spectrum fungicide propiconazole (as Tilt; Syngenta Crop Protection) applied as a seed treatment to rice, resulted in a $92 \%$ decrease in blackbird consumption of treated seeds in a laboratory preference test. In rice field trials, no difference in total harvest was observed between treated and untreated plots. However, applications could not be made within 35 days of harvest and residues remaining on the seed at harvest may have been insufficient for repellency. Propiconazole currently has 81 tolerances for foliar or nonbearing treatments on crops including stone fruits and blueberries.

Werner et al. (2008a) found that seeds treated with flutolanil (proprietary formulation, Gowan Company) was effective at reducing blackbird consumption of rice by as much as $77 \%$ under laboratory conditions. In a drilled seed 
trial, Werner et al. (2008a) reported 50\% fewer seedlings in an untreated rice plot versus a plot planted with flutolanil treated seed. Flutolanil has established tolerances on 6 grain crops, but not in soft fruit.

We are not proposing propiconazole or flutolanil chemicals for registration. Even so, they may warrant further evaluation. If one of these products could be used without reformulating and simply required a higher application rate or applications closer to harvest than currently allowed on the label, adding an avian repellent use may only require establishing a tolerance at application rates suitable for repellency. However, since they do not currently have avian repellent uses, they may require more robust field efficacy data. Approximate cost projections for this scenario include $\$ 673,000$ for development of residue tolerance and a multi-site field efficacy study (Table 1). As mentioned above, this estimate does not include the cost of post-application exposure, applicator exposure, or spray drift data. PRIA fees and timeframes are similar to adding a new use for an existing avian repellent, \$59,976 and a review time of 10 to 15 months depending upon whether the EPA considers the product 'Reduced Risk' . The approximate cost for this option is $\$ 733,000$.

\section{Registering a New Formulation of an Existing Pesticide Product as an Avian Repellant on Fruit Crops}

Registering a new food use for an existing product is our final option. However, the product might require reformulation to be an effective avian repellent. In this case, data costs would be approximately $\$ 782,000$. The increased cost is attributed to the additional product chemistry data required to support the new product (Table 1). As mentioned above, this estimate does not include the cost of post-application exposure, applicator exposure, or spray drift data. PRIA fees and review timeframes would be similar to other requests for an additional food use to an existing product, or $\$ 59,976$ and 10 to 15 months. Total cost for this option would be approximately $\$ 842,000$.

\section{Discussion}

There is an obvious need for alternative management options for alleviating bird damage in soft fruit crops. The options currently available, such as exclusion, can be effective, but have high initial start up and maintenance costs. Methyl anthranilate is the one registered chemical control option but the effectiveness of methyl anthranilate in fruit and grain crops has been questioned (Cummings et al. 1995, Avery et al. 1996, Blackwell et al. 2001, Werner et al. 2005). Indeed, registration of an effective avian repellent is dependent upon reconciliation of sufficient repellent concentrations with allowable residue tolerance (Werner et al. 2008b, 2009, 2010).

We conclude that the development costs associated with a new active ingredient for soft fruit may be prohibitive. The return on a registrant's investment may not be sufficient unless other markets could be developed for the same compound. A strategy that may yield expedited and cost effective results for the soft fruit industry may be partnering with the agrochemical industry and investing in additional research on currently registered pesticides. The research cited in this manuscript indicates fungicides may be promising. If a currently registered chemical with established food tolerances was identified as an effective avian repellent, a product registration might be obtained within the following 4 years.

\section{Literature Cited}

Avery, M.L., T.M. Primus, J. Defrancesco, J.L. Cummings, D.G. Decker, J.S. Humphrey, J.E. Davis, \& R. Deacon. 1996. Field evaluation of methyl anthranilate for deterring birds eating blueberries. Journal of Wildlife Management, 60(4): 929-934.

Blackwell, B.F., D.A. Helon, \& R.A. Dolbeer. 2001. Repelling sandhill cranes from corn: Whole-kernel experiments with captive birds. Crop Protection, 20(1): 65-68.

Clark, L., P.S. Shah, \& J.R. Mason. 1991. Chemical repellency in birds: relationship between chemical structure and avoidance response. Journal of Experimental Zoology, 260(3): 310-322.

Cummings, J.L., M.L. Avery, P.A. Pochop, J.E. Davis, D.G. Decker, H.W. Krupa, \& J.W. Johnson. 1995. Evaluation of a methyl anthranilate formulation for reducing bird damage to blueberries. Crop Protection, 14(3): 257-259.

Linz, G.M., H.J. Homan, A.A. Slowik, \& L.B. Penry. 2006. Evaluation of registered pesticides as repellents for reducing blackbird (Icteridae) damage to sunflower. Crop Protection, 25: 842-847.

US EPA. 1987. Registration Standard: Methiocarb. Environmental Protection Agency, NTIS \#PB87-190898.

US EPA 1992. Reregistration Eligibility Decision Document, Methiocarb, List A, Case 0577. Environmental Protection Agency, Special Review and Reregistration Division. 207p.

US EPA 2007. Environmental Protection Agency, 40 CFT Parts 9 and 158, Pesticides: Data Requirements for Conventional Chemicals. Federal Register, 72(207): 600-934.

Werner, S.J., J.C. Carlson, S.K. Tupper, M.M. Santer, \& G.M. Linz. 2009. Threshold concentrations of and anthraquinone-based repellent for Canada geese, red-winged blackbird and ringnecked pheasants. Applied Animal Behavior Science, 121:190196.

Werner, S.J., J.L. Cummings, P.A. Pipas, S.K. Tupper, \& R.W. Byrd. 2008a. Registered pesticides and citrus terpenes as black bird repellents for rice. Journal of Wildlife Mangement, 72(8):18631868.

Werner, S.J., J.L. Cummings, S.K. Tupper, D.A. Goldade, \& D. Beighley. 2008b. Blackbird repellency of selected registered pesticides. Journal of Wildife Management, 72(4):1007-1011.

Werner, S.J., H.J. Homan, M.L Avery, G.M. Linz, E.A. Tillman, A.A. Slowik, R.W. Byrd, \& M.J. Goodall. 2005. Evaluation of Bird Shield TM as a blackbird repellent in ripening rice and sunflower. Wildlife Society Bulletin, 33(1):251-257.

Werner, S.J., G.M. Linz, S.K. Tupper, \& J.C. Carlson. 2010. Laboratory efficacy of chemical repellents for reducing blackbird damage in rice and sunflower crops. Journal of Wildlife Management, 74:1400-1404.

John Eisemann is the Registration Manager with the USDA, Animal and Plant Health Inspection Service,Wildlife Services, National Wildlife Research Center, Fort Collins, Colorado. He earned a baccalaureate degree in wildlife biology from Colorado State University, and Masters' degrees in environmental sciences at the University of Maryland in Wildlife Biology. His current product registration efforts are related to rodent eradication on islands, contraceptives for wildlife, avian and mammalian repellents, and other chemical tools for managing vertebrate pest damage. 
Scott Werner is a Research Wildlife Biologist with the USDA, Animal andPlant Health Inspection Service, Wildlife Services, National Wildlife Research Center, Fort Collins, Colorado. Scott's research interests include the physiological bases of food and habitat selection, and the development of non-lethal repellents for wildlife.
Jeanette O'Hare is a Pesticide Registration Specialist with the USDA,Animal and Plant Health Inspection Service, Wildlife Services, National Wildlife Research Center, Fort Collins, Colorado. Baccalaureate and Master of Arts degrees were obtained at the College of Saint Mary and the University of Nebraska, both in Omaha, Nebraska. Current responsibilities are to assure studies involving pesticides, drugs and vaccines to meet all applicable Federal and State regulatory requirements, and respond to technical and regulatory inquiries.

Similar articles that appeared in Outlooks on Pest Management include - 20102 I (4) I8I 